\title{
Postharvest quality of Frangi papaya after double hot-water dip followed by various cooling water temperatures
}

\begin{abstract}
'Frangi' papaya is F1 hybrid cultivar which was developed and released by a Malaysian company in 2006. As quarantine requirements, papaya fruit need to go through double hot water immersion. Immediate cooling of fruit after hot water immersion is needed to remove the heat from fruit. Since 'Frangi' papaya is a new hybrid and its physiology may differ from other cultivar. Therefore, this study was carried out to determine optimum cooling water temperature for 'Frangi' papaya after hot water dipped treatment. Mature green papaya fruit were dipped in $42^{\circ} \mathrm{C}$ for $30 \mathrm{~min}$ then $49^{\circ} \mathrm{C}$ for $20 \mathrm{~min}$. This followed by cooling the fruit with (i) running tap water of $26^{\circ} \mathrm{C}$, (ii) cool water of $15^{\circ} \mathrm{C}$ and (iii) cool water of $4^{\circ} \mathrm{C}$. The cooling was carried out for $20 \mathrm{~min}$ for all the temperature of water. Fruit that did not cool with water act as control. The fruit was then initiated to ripening using $1 \mathrm{ml} \mathrm{L}-1$ ethylene. Fruit peel colour $\left(\mathrm{L}^{*}, \mathrm{C}^{*}\right.$ and $\mathrm{h}^{\circ}$ ), firmness, soluble solids concentration (SSC), titratable acidity (TA) and $\mathrm{pH}$ at day 0,3 and 6 were being analysed. The $\mathrm{h}^{\circ}, \mathrm{SSC}$, TA and $\mathrm{pH}$ of fruit was affected significantly by interaction between water temperature $\times$ ripening day. There were no significant differences in $\mathrm{h}^{\circ}$ values among treatment at ripening day 0 and 6 . At day 3 , control has significant lower ho than fruit cooled with 15 and $4{ }^{\circ} \mathrm{C}$ of water. The firmness of 'Frangi' papaya was not affected by water temperature but decreased significantly when fruit ripened from day 0 to 3 . At day $0, \mathrm{SSC}$ was not affected by water temperature. By day 6 , SSC of control was significantly higher than others cool water treated fruit. At day 0 , the control fruit has significant lower TA than others treatment fruit. As ripening progressed, no significant differences were found among treatments. For $\mathrm{pH}$, all treatments did not show any differences at day 0 . By day 3 , fruit cooled with $26^{\circ} \mathrm{C}$ water has the highest $\mathrm{pH}$ but by day 6 , fruit cooled with $4^{\circ} \mathrm{C}$ has the highest $\mathrm{pH}$. The quality of 'Frangi' papaya whether cooled with water or not after hot water dip was almost the same except SSC and $\mathrm{pH}$.
\end{abstract}

Keyword: Peel colour; Firmness; Soluble solids concentration; Titratable acidity; pH 